\title{
PENDAMPINGAN PENGEMBANGAN KEPROFESIAN BERKELANJUTAN (CONTINUING PROFESSIONAL DEVEPLOVMENT) BAGI GURU SEKOLAH DASAR KECAMATAN DELI TUA
}

\author{
Halimatussakdiah, Nurmayani, Laurensia Masri Pa. \\ Dosen Jurusan PPSD Prodi PGSD FIP UNIMED \\ Jln. Willem Iskandar Psr. V. Kotak Pos No. 1589-Medan 20221 Telp.(061)6623943 \\ Email: halimatussakdiahnst11@gmail.com
}

\begin{abstract}
ABSTRAK
Hasil identifikasi terhadap 38 orang guru SD di SDN. 101799 Deli Tua dan SDN. 101800 Kecamatan Deli Tua Kabupaten Deli Serdang ditemukan permasalahan guru sulit dalam melaksanakan Pengembangan Keprofesian Berkelanjutan (PKB). Solusi yang dilakukan oleh tim pengabdian dari Unimed yaitu pendampingan dalam bentuk workshop, lesson study, focuss group discussion (FGD), praktik perbaikan pembelajaran di kelas, dan penyusunan laporan perbaikan pembelajaran dalam bentuk Penelitian Tindakan Kelas (PTK). Target kegiatan ini meningkatkan kompetensi mitra dalam melakukan Pengembangan Keprofesian Berkelanjutan (PKB). Selanjutnya produk kegiatan PKB ini adalah sebagai berikut : (1) Adanya video perbaikan pembelajaran guru di kelas, (2) Adanya produk berupa laporan penelitian tindakan kelas dan jurnal ilmiah. Selanjutnya, hasil capaian indikator kinerja yaitu: Ada kemauan guru dalam perbaikan praktik pembelajaran di kelas berdasarkan evaluasi video pembelajarannya (60\%), sudah ada guru yang menyelesaikan PTK $(40 \%)$ dan sudah ada judul artikel ilmiah guru yang terbit pada School Education Journal Prodi PGSD Vol.3 No.2 Juni 2015 (40\%). Pendampingan yang dilakukan dapat meningkatkan Pengembangan Keprofesian Berkelanjutan (Continuing Professional Deveplopment) bagi guru SD di SDN. 101799 Deli Tua dan SDN. 101800 Kecamatan Deli Tua Kabupaten Deli Serdang.
\end{abstract}

Kata Kunci: Pendampingan, PKB, Guru SD

\section{PENDAHULUAN}

Kementerian Pendidikan dan Kebudayaan telah menetapkan kebijakan, bahwa guru wajib melaksanakan Pengembangan Keprofesian Berkelanjutan (PKB) atau Continuing Professional Deveplopment (CPD). PKB guru ini diatur dalam pasal 11 huruf $\mathrm{c}$ dan pasal 14 ayat (2) Permeneg PAN dan RB No.16 tahun 2009 tentang Jabatan Fungsional Guru dan Angka Kreditnya dan pasal 3 ayat (2) huruf c Peraturan Bersama Mendiknas dan Kepala Badan Kepegawaian Negara N0.03/V/PB/2010 tentang pelaksanaan Jabatan Fungsional Guru dan Angka Kreditnya. Kebijakan tersebut pada prinsipnya bertujuan untuk menjamin bahwa guru melaksanakan pekerjaannya secara professional serta menjamin bahwa layanan pendidikan yang diberikan oleh guru berkualitas.

Kebijakan tersebut mengisyarakat bahwa tugas guru tidak hanya mengajar, membimbing dan menilai, tetapi juga harus mengembangkan profesi keguruannya yang meliputi pengembangan diri, publikasi ilmiah, dan karya inovatif. PKB adalah bentuk pembelajaran berkelanjutan bagi guru sebagai aktivitas reflektif yang dirancang untuk meningkatkan kemampuan, pengetahuan, pemahaman, dan keterampilan guru. PKB juga bermakna bagaimana cara guru memelihara, memperbaiki, memperluas pengetahuan dan keterampilan mereka 
serta mengembangkan kualitas diri yang diperlukan dalam kehidupan professionalnya.

Hasil identifikasi pada 2014 (Januari s.d April) terhadap 38 orang guru SD di SDN. 101799 Deli Tua dan SDN. 101800 Kecamatan Deli Tua Kabupaten Deli Serdang ditemukan permasalahan sebagai berikut : (1) Guru belum menyusun silabus dan RPP sendiri, dokumen yang ada adalah hasil perumusan di MGMP atau mengadopsi langsung model silabus dan RPP yang diterbitkan oleh PUSKUR; (2) Guru melaksanakan pembelajaran sesuai jadwal, tetapi hanya $40 \%$ guru yang melakukan pembelajaran sesuai dengan RPP yang dimiliki; (3) Buku yang digunakan guru sebagai literatur pembelajaran terbatas pada buku pegangan belajar siswa; (4) Guru enggan untuk memperbaiki pembelajaran di kelas (misalnya belum menerapkan pendekatan, model, metode, strategi, dan belum memodifikasi media pembelajaran. (5) Penilaian yang dilakukan guru masih terbatas pada objektif tes, belum tersedia penilaian yang dilengkapi dengan rubrik penilaian dan portofolio; (6) Kegiatan remedial belum dilakukan berdasarkan diagnosis permasalah belajar siswa, dan guru juga tidak melakukan program pengayaan; (7) Guru tidak memiliki karya ilmiah dan laporan penelitian tindakan kelas (PTK) karena guru kurang memiliki pemahaman konkret bagaimana merancang karya ilmiah dan PTK. Sehingga jarang sekali ada publikasi ilmiah di sekolah tersebut.

Akibat dari permasalahanpermasalah tersebut berdampak pula pada kenaikan pangkat guru di sekolah tersebut. Hal ini dapat dibuktikan dari data berikut.

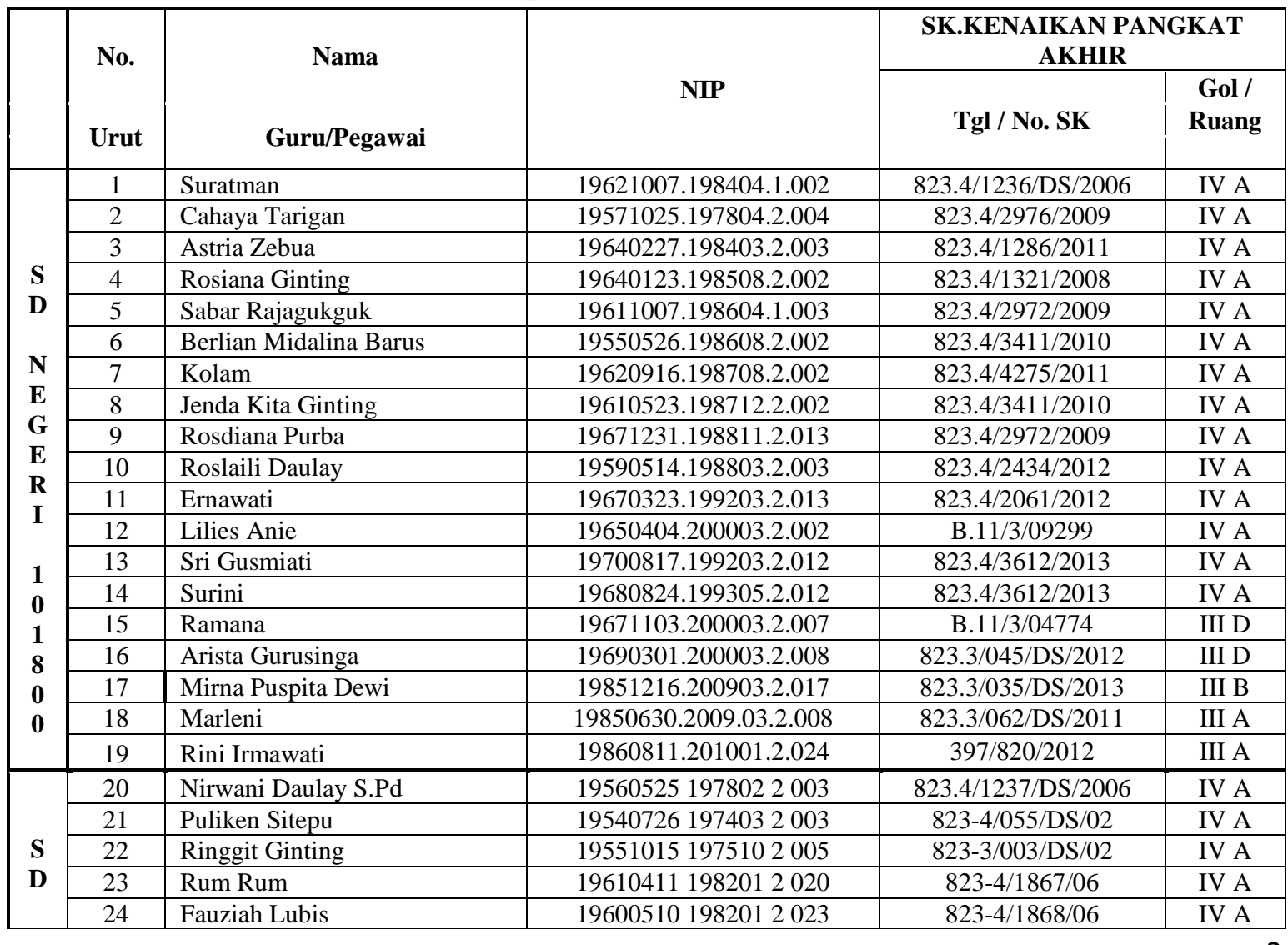




\begin{tabular}{|c|c|l|c|c|c|} 
& 25 & Norma Barus & 196201111983042007 & $823-4 / 1869 / 06$ & IV A \\
\cline { 2 - 6 } $\mathbf{N}$ & 26 & Roita Manurung & 196007021983042006 & $823-4 / 778 / 07$ & IV A \\
\cline { 2 - 6 } $\mathbf{E}$ & 27 & Sutrisno & 195901201984041002 & $823-4 / 773 / 07$ & IV A \\
\cline { 2 - 6 } $\mathbf{G}$ & 28 & Bersih & 196112311986042010 & $823-3 / 074 / 06$ & IV A \\
\cline { 2 - 6 } & 29 & Darna & 195903011988032005 & $823-3 / 027 / 105 / 08$ & IV A \\
\cline { 2 - 6 } $\mathbf{R}$ & 30 & Nuraini Nasution & 197006201992032013 & $823-3 / 027 / 05 / 08$ & IV A \\
\cline { 2 - 6 } $\mathbf{I}$ & 31 & Sui Tjin (Juli) & 196410122000032001 & BII/b/11267 & III D \\
\cline { 2 - 6 } & 32 & Sederhana & 196306161999072002 & $823-3 / 063 / \mathrm{DS} / 07$ & III B \\
$\mathbf{1}$ & 33 & Meri Rosmida & 196204211996122002 & $823-3 / 042 / \mathrm{D} / 08$ & III C \\
$\mathbf{0}$ & 34 & Sabariah & 196107042000122003 & $823-3 / 012 / \mathrm{DS} / 08$ & III C \\
$\mathbf{1}$ & 35 & Dewi Warna Fransiska. G & 196912112008012021 & $885 / 2008$ & II B \\
$\mathbf{7}$ & 36 & Rahauli & 196102151984042003 & $268 / 2011$ & III D \\
$\mathbf{9}$ & 37 & Rina Mariana & 198403032009032010 & $565 / 2010$ & II C \\
$\mathbf{9}$ & 38 & Leni Maisyarah & 198511022010012026 & & IIIA \\
\hline
\end{tabular}

Berdasarkan data di atas, dapat diuraikan temuan sebagai berikut.

\begin{tabular}{|c|c|c|c|c|c|c|c|}
\hline \multirow[t]{2}{*}{ Keterangan } & \multicolumn{7}{|c|}{ Gol/ Ruang } \\
\hline & IV A & III D & III C & III B & III A & II C & II B \\
\hline \multirow{7}{*}{$\begin{array}{l}\text { Rentang } \\
\text { Waktu } \\
\text { SK.Kenaikan } \\
\text { Pangkat Akhir } \\
\text { sampai } 2014\end{array}$} & 2 org $=12$ tahun & 1 org $=10$ tahun & $\begin{array}{l}2 \text { org }=6 \\
\text { tahun }\end{array}$ & $\begin{array}{l}1 \text { org }=7 \\
\text { tahun }\end{array}$ & $\begin{array}{l}1 \text { org }=4 \\
\text { tahun }\end{array}$ & $\begin{array}{l}1 \text { org }=4 \\
\text { tahun }\end{array}$ & 1 org $=6$ tahun \\
\hline & 6 org $=8$ tahun & 2 org $=3$ tahun & & $\begin{array}{l}1 \text { org }=2 \\
\text { tahun }\end{array}$ & $\begin{array}{l}1 \text { org }=3 \\
\text { tahun }\end{array}$ & & \\
\hline & 2 org $=7$ tahun & 1 org $=2$ tahun & & & $\begin{array}{l}1 \text { org }=2 \\
\text { tahun }\end{array}$ & & \\
\hline & 3 org $=6$ tahun & & & & & & \\
\hline & 6 org $=5$ tahun & & & & & & \\
\hline & 2 org $=4$ tahun & & & & & & \\
\hline & 2 org $=3$ tahun & & & & & & \\
\hline $\begin{array}{c}\text { Jumlah Guru } \\
38 \text { org }\end{array}$ & 25 org & 4 org & 2 org & 2 org & 3 org & 1 org & 1 org \\
\hline
\end{tabular}

Data di atas menunjukkan bahwa dari 38 orang guru terdapat 25 orang golongan IV/a, 4 orang III/d, 2 orang golongan III/c, 2 orang golongan III/b, 3 orang golongan III/a, 1 orang golongan II/b, dan 1 orang II/c. Dari 38 jumlah guru, banyak yang berada digolongan IVa. Selanjutnya dilihat dari lamanya tahun SK. KENAIKAN PANGKAT AKHIR menunjukkan lamanya rentang waktu bagi guru untuk melakukan kenaikan pangkat sampai tahun 2014. Guru yang bernama Suratman dan Nirwani Daulay naik pangkat dengan SK pangkat terakhir pada 2006 dan 2014 belum mengajukan kenaikan pangkat, berarti sekitar 8 tahun mereka belum juga naik pangkat. Ini merupakan jangka waktu yang cukup lama.

Ketika dikonfirmasi, guru mengatakan ada kesulitan dalam melaksanakan PKB. Begitu pula alasan guru-guru lain yang juga belum naik pangkat berkisar sekitar 4 sampai 12 tahun. Mereka mengeluhkan beratnya aturan baru kenaikan pangkat yang wajib melaksanakan PKB.

Mencermati temuan tersebut, dalam rangka pengembangan keprofesian guru berkelanjutan perlu dilakukan peningkatan kapasitas guru berkelanjutan yang terkait dengan 7 (tujuh) permasalahan yang dihadapi guru. Dosen-dosen Unimed yang tergabung dalam tim pengabdi melakukan pendampingan untuk memecahkan berbagai permasalahan tersebut.

Di samping itu, dosen-dosen Unimed juga memotivasi guru untuk melakukan Penelitian Tindakan Kelas (PTK), dalam rangka mencari akar permasalahan yang terjadi di kelas. Masalah yang muncul di kelas tentu tidak boleh dibiarkan begitu saja terjadi, namun 
guru harus memperbaiki permasalahan pembelajaran (misalnya menerapkan pendekatan, model, metode, strategi, dan memodifikasi media dan alat peraga). Dengan demikian Tindakan baru yang ditemukan dan diyakini guru bisa secara efektif meningkatkan proses dan hasil pembelajaran siswa di kelas.

Pendampingan yang dilakukan tim pengabdi dari Unimed dilaksanakan melalui kegiatan kolektif profesi guru (KKG/MGMP), dilakukan dalam bentuk workshop, lesson study, focuss group discussion (FGD), perbaikan pembelajaran di kelas, dan penyusunan laporan perbaikan pembelajaran dalam bentuk Penelitian Tindakan Kelas (PTK).

Berdasarkan uraian di atas Pendampingan Pengembangan Keprofesian Berkelanjutan (Continuing Professional Deveplopment) bagi guru SD di SDN. 101799 Deli Tua dan SDN. 101800 Kecamatan Deli Tua Kabupaten Deli Serdang memiliki arah dan tujuan yang jelas. Tidak saja untuk memenuhi hasrat guru dalam rangka kenaikan pangkat tetapi juga dapat membantu peserta didik untuk memahami dan mendalami ilmu pengetahuan berdasarkan pengetahuan, pengalaman, strategi dan metode baru serta pengembangan media pembelajaran yang diterapkan oleh guru. Dengan begitu, perbaikan pembelajaran di dalam kelas diharapkan menghasilkan pembelajaran yang menarik, bermutu, dan menciptakan pembelajaran yang inovatif.

\section{METODE PELAKSANAAN}

\section{Rancangan Kegiatan}

Dengan permasalahan-permasalahan PKB sebagaimana digambarkan sebelumnya dan untuk mencapai tujuan kegiatan pengabdian ini, maka rancangan pada kegiatan ini adalah perencanaan (planning), pelaksanaan (action), refleksi (reflection) dan tindak lanjut (follow up). Secara spesifik kerangka dasar pelaksanaan kegiatan ini diuraikan sebagai berikut.

1. Identifikasi kebutuhan guru yang dilakukan dengan menelaah Pengembangan Keprofesian Berkelanjutan (PKB)

2. Kesepakatan dua mitra melalui penandatanganan surat pernyataan dukungan pelaksanaan kegiatan.

3. Tim Pengabdi membuat modul Pengembangan Keprofesian Berkelanjutan (PKB)

4. Guru berperan aktif mengikuti pendampingan PKB melalui kegiatan kolektif profesi guru (KKG/MGMP), dilakukan dalam bentuk workshop, lesson study, focuss group discussion (FGD) yang dilaksanakan oleh tim pengabdi di sekolah.

5. Memotivasi guru supaya melakukan dokumentasi dengan video ketika melakukan perbaikan pembelajaran di kelas (menerapkan pembelajaran inovatif dengan pendekatan, model, metode, strategi, media dan alat peraga)

6. Memperkenalkan prinsip PTK kepada guru, mendampingi guru dalam menyusun proposal PTK, melaksanakan PTK, dan menulis laporan hasil PTK.

7. Seminar dilakukan untuk melaporkan dan mendiskusikan hasil penelitian guru 
8. Penerbitan jurnal sebagai tindak lanjut setelah PTK mitra selesai disusun.

\section{HASIL YANG DICAPAI}

Adapun hasil yang dicapai pada kegiatan pendampingan ini berupaya meningkatan profesionalisme guru-guru SD di Kecamatan Deli Tua. Sebagai pemenuhan kebutuhan guru dalam melaksanakan Pengembangan Keprofesian Berkelanjutan (PKB) guru di SD Kecamatan Deli Tua Kabupaten Deli Serdang, dosen-dosen Unimed sebagai tim pengabdi bermaksud membantu guru SD dalam mengatasi permasalahan pembelajaran di kelas melalui kegiatan pendampingan yang dilakukan melalui kegiatan kolektif profesi guru (KKG), dilakukan dalam bentuk workshop, lesson study, focuss group discussion (FGD), perbaikan pembelajaran di kelas, dan penyusunan laporan perbaikan pembelajaran dalam bentuk Penelitian Tindakan Kelas (PTK).

Kebermanfaatan kegiatan pendampingan dan pelatihan selama beberapa bulan yang dilaksanakan tim pelaksana dari UNIMED dapat dirasakan sangat baik. Tim pelaksana membuktikan bahwa ada peningkatan persentase kualitas pembelajaran guru SDN. 101799 Deli Tua dan SDN. 101800 Kecamatan Deli Tua Kabupaten Deli Serdang. Adapun hasil yang dicapai pada kegiatan yaitu:

1. Ada kemauan guru dalam perbaikan praktik pembelajaran di kelas berdasarkan evaluasi video pembelajarannya $(60 \%)$

2. Sudah ada guru yang menyelesaikan PTK $(40 \%)$

3. Sudah ada judul artikel ilmiah guru yang terbit pada School Education Journal Prodi PGSD Vol.3 No.2 Juni 2015 (40\%).

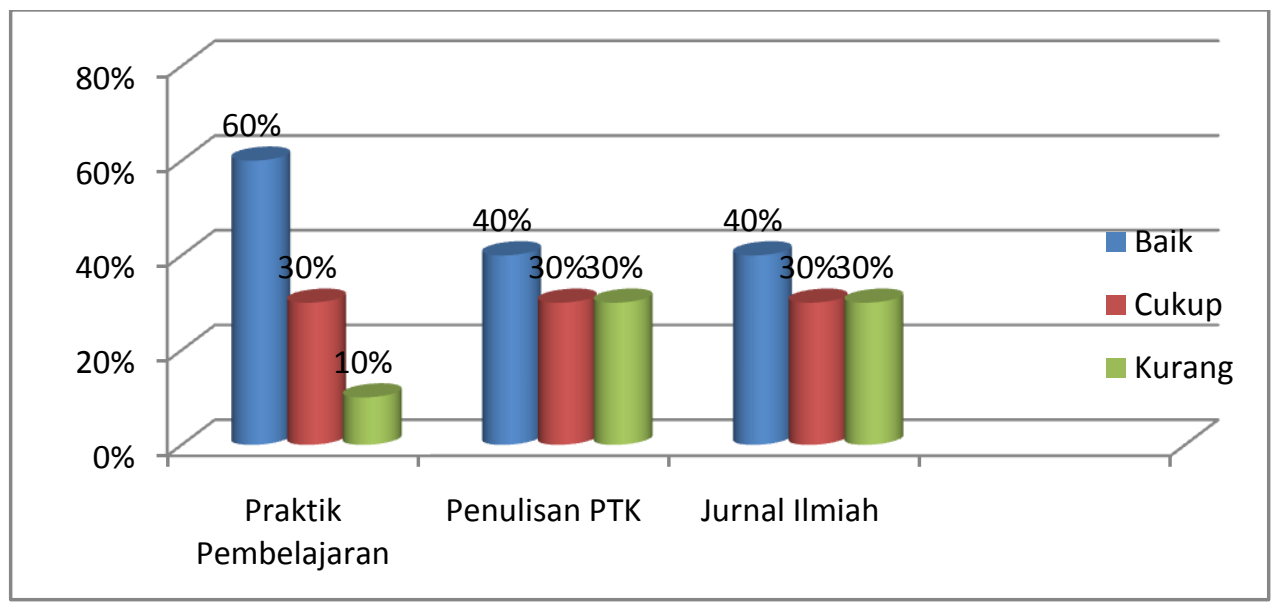

Berdasarkan grafik di atas dapat dijelaskan bahwa dari 38 orang guru yang mengikuti pelatihan ada $60 \%$ yang melakukan perbaikan praktik pembelajaran di kelas (misalnya menerapkan pendekatan, model, metode, strategi, dan memodifikasi media pembelajaran) dan $40 \%$ masih belum mampu memperbaiki pembelajaran di kelas, pengajaran guru bersifat konvensional. Selanjutnya $40 \%$ orang guru yang mampu menghasilkan laporan PTK dan jurnal ilmiah dan $60 \%$ orang guru lainnya mengaku tidak mampu 
menyelesaikan dengan berbagai alasan.

\section{Pencapaian indikator}

Sesuai dengan target dari kegiatan ini yaitu dimulai dari pemaparan tentang PTK, pelatihan penulisan proposal PTK dilanjut dengan pelaksanaan di kelas masing-masing guru sampai akhirnya diperoleh data. Setelah itu guru-guru melakukan pengolahan data dan menyusun laporan akhir dari PTK mereka masing-masing secara lengkap.

Berdasarkan laporan akhir guruguru tersebut, mereka dibimbing kembali untuk membuat artikel sebagai karya ilmiahnya untuk diterbitkan dalam jurnal khusus bagi guru-guru. Sejauh ini terdapat kendala yaitu sebagian besar guru-guru tersebut tidak mnguasai ICT (tidak mampu menggunakan komputer), sehingga mereka tersendat pada penulisan proposal dan laporan akhir. Sebagai jalan keluar, mereka meminta pertolongan keluarga masing-masing yang mampu menggunakan komputer.
Perbaikan pembelajaran di kelas juga sudah mendapat perhatian dari guruguru. Berdasarkan video pembelajaran awal, guru-guru menyadari banyak kelemahan dan kekurangan cara mengajar mereka di kelas, lalu setelah dievaluasi maka guru berkenan memperbaiki cara mengajar dengan menerapkan metode, model, menerapkan media dll. Lalu selanjutnya video pembelajaran kedua dibuat untuk mengetahui sejauhmana peningkatan kualitas mengajar dari video sebelumnya.

Selanjutnya, hasil capaian indikator kinerja yang dirancang sebelumnya yaitu: Ada kemauan guru dalam perbaikan praktik pembelajaran di kelas berdasarkan evaluasi video pembelajarannya (60\%), sudah ada guru yang menyelesaikan PTK (40\%) dan sudah ada judul artikel ilmiah guru yang terbit pada School Education Journal Prodi PGSD Vol.3 No.2 Juni 2015 (40\%)

Tabel Pencapaian Indikator kerja dan Target Capaian Persentase

\begin{tabular}{|l|l|l|l|l|}
\hline Produk & Produk & Target & Capaian & $\begin{array}{l}\text { Persentase } \\
\text { capaian }\end{array}$ \\
\hline Video pembelajaran & Ada & Ada & Ada & $60 \%$ \\
\hline $\begin{array}{l}\text { Penulisan PTK yang telah } \\
\text { dilaksanakan guru }\end{array}$ & Ada & Ada & Ada & $40 \%$ \\
\hline Jurnal Artikel Ilmiah guru & Ada & Ada & Ada & $40 \%$ \\
\hline
\end{tabular}

Berdasarkan luaran kegiatan ini adalah minimal $10 \%$ dari peserta menghasilkan laporan PTK dan artikel ilmiah, sedangkan setelah tindakan ada $40 \%$ orang guru yang menghasilkan laporan PTK dan artikel ilmiah.

\section{KESIMPULAN}

Adapun kesimpulan kegiatan ini yaitu : Pendampingan (dilakukan dalam bentuk workshop, lesson study, focuss group discussion (FGD), perbaikan pembelajaran di kelas, dan penyusunan laporan PTK) dapat meningkatkan Pengembangan Keprofesian Berkelanjutan (Continuing Professional Deveplopment) bagi guru SD di SDN. 101799 Deli Tua dan SDN. 101800 Kecamatan Deli Tua Kabupaten Deli 
Serdang. Adapun hal-hal yang disarankan dari hasil kegiatan ini adalah:

1. Perlu dilakukan kegiatan bagi guruguru yang berhubungan dengan kebutuhan mereka dalam melaksanakan pembelajaran di kelas, seperti: model pembelajaran dan PTK serta pelatihan ICT.

2. Kegiatan seperti ini juga perlu dilakukan di daerah-daerah lain karena masih banyak guru-guru yang belum mampu membuat PTK sehingga mereka tidak bisa untuk naik pangkat.

\section{DAFTAR RUJUKAN}

Aqib, Zainal. 2013. Pengembangan Keprofesian Berkelanjutan Bagi Guru. Bandung: CV.Yrama Widya. . 2008. Penelitian Tindakan Kelas. Bandung: CV.Yrama Widya

Arikunto. 2010. Penelitian Tindakan Kelas. Jakarta: Rineka Cipta.

Kemdikbud. 2013. Panduan Pelaksanaan

Penelitian dan Pengabdian Kepada Masyarakat di Perguruan Tinggi (Edisi IX). Jakarta.

Kemendiknas. 2010. Pedoman Pengelolaan Pengembangan Keprofesian Berkelanjutan (PKB) (Buku 1). Pusat Pengembangan Profesi Pendidik Badan Pengembangan Sumber Daya Manusia Pendidikan dan Penjaminan Mutu Pendidikan Kemendiknas, Jakarta.

Kemendiknas. 2011.

Pedoman

Pengelolaan Pengembangan Keprofesian Berkelanjutan
(PKB) (Buku 4). Pusat Pengembangan Profesi Pendidik Badan Pengembangan Sumber Daya Manusia Pendidikan dan Penjaminan Mutu Pendidikan Kemendiknas, Jakarta.

Kemendiknas. 2011. Pedoman Pengelolaan Pengembangan Keprofesian Berkelanjutan (PKB) (Buku 5). Pusat Pengembangan Profesi Pendidik Badan Pengembangan Sumber Daya Manusia Pendidikan dan Penjaminan Mutu Pendidikan Kemendiknas, Jakarta.

Kemendiknas. 2011. Peraturan Menteri Negara Pendayagunaan Aparatur Negara dan Reformasi Birokrasi Nomor 16 Tahun 2009 Tentang Jabatan Fungsional Guru dan Angka Kreditnya. Pusat Pengembangan Profesi Pendidik Badan Pengembangan Sumber Daya Manusia Pendidikan dan Penjaminan Mutu Pendidikan Kemendiknas, Jakarta.

Peraturan Pemerintah RI Nomor 74 Tahun 2008. Tentang Guru (Lembaran Negera RI Tahun 2008 Nomor 194).

Suhardjono. 2011. PTK sebagai Kegiatan Pengembangan Profesi Guru. Jakarta : PT. Bumi Aksara. 